\title{
Analysis of wind speed data and wind energy potential in three selected locations in south-east Nigeria
}

\author{
Sunday O Oyedepo ${ }^{1}$, Muyiwa S Adaramola ${ }^{2^{*}}$ and Samuel S Paul ${ }^{3}$
}

\begin{abstract}
In this study, the wind speed characteristics and energy potential in three selected locations in the southeastern part of Nigeria were investigated using wind speed data that span between 24 and 37 years and measured at a height of $10 \mathrm{~m}$. It was shown that the annual mean wind speed at a height of $10 \mathrm{~m}$ for Enugu, Owerri and Onitsha are $5.42,3.36$ and $3.59 \mathrm{~m} / \mathrm{s}$, respectively, while the annual mean power densities are $96.98,23.23$ and $28.34 \mathrm{~W} / \mathrm{m}^{2}$, respectively. It was further shown that the mean annual value of the most probable wind speed are 5.47, 3.72 and $3.50 \mathrm{~m} / \mathrm{s}$ for Enugu, Owerri and Onitsha, respectively, while the respective annual value of the wind speed carrying maximum energy are $6.48,4.33$ and $3.90 \mathrm{~m} / \mathrm{s}$. The performance of selected commercial wind turbine models (with rated power between 50 and 1,000 kW) designed for electricity generation and a windmill (rated power, $0.36 \mathrm{~kW}$ ) for water pumping located in these sites was examined. The annual energy output and capacity factor for these turbines, as well as the water produced by the windmill, were determined. The minimum required design parameters for a wind turbine to be a viable option for electricity generation in each location are also suggested.
\end{abstract}

Keywords: Mean wind speed, Wind power density, South-east Nigeria, Electricity, Water pumping

\section{Background}

The quest to reduce environmental impacts of conventional energy resources and, more importantly, to meet the growing energy demand of the global population had motivated considerable research attention in a wide range of environmental and engineering application of renewable form of energy. It is recognized that wind energy, as a renewable energy source, has stood out as the most valuable and promising choice. Wind energy by nature is clean, abundant, affordable, inexhaustible and environmentally preferable. Due to its many advantages, wind energy has also become the fastest growing renewable source of energy in both developed and developing countries. For example, wind energy is widely used to produce electricity in countries like Denmark, Spain, Germany, USA, China and India. Interestingly, the global cumulative installed capacity of wind power had increased sharply from 6,100 MW in 1996 to about

\footnotetext{
* Correspondence: muyiwa.adaramola@usask.ca

${ }^{2}$ Department of Energy and Process Engineering, Norwegian University of

Science and Technology, Trondheim, NO-7491, Norway

Full list of author information is available at the end of the article
}

237,669 MW in 2011 [1]. In Africa, for example, Egypt, Morocco and Tunisia are the leading countries with installed capacities of 550, 291 and 114 MW, respectively, at the end of 2011 [1].

The increasing energy demand, the rapidly depleting fossil fuel reserves and the environmental problems associated with the use of fossil fuel have necessitated the development of alternative energy sources like wind energy for electricity generation in Nigeria. It is reported that the electricity production in Nigeria as of the end of 2010 is less than 4,000 MW due to fluctuations in the availability and maintenance of production sources, leading to a shortfall in supply [2]. However, analyses of available wind data for selected cities have confirmed a high prospect of wind energy resources in Nigeria. Several studies on renewable sources of energy have also been performed. A detailed review and discussion of these studies can be found in [2-6] and are not repeated here. Worthy of mention here from these studies, however, is that the effective utilization of wind energy at a typical location requires sound knowledge of the wind characteristics and accurate wind data analysis. For 
example, the choice of wind turbine design must be based on the average wind velocity at a selected wind turbine installation site [7]. Prior studies have also shown that the wind flow patterns are influenced by terrains, vegetation and water bodies.

Although several studies have been performed to investigate the characteristics and pattern of wind speed across Nigeria, less attention has been given to sites in the southeast region. According to [8,9], the few reported studies on wind speed in this part of the country were limited to wind speed distributions, while less attention was paid to the wind energy potential evaluation. The focus of this study is, therefore, to evaluate the wind energy potential in three selected locations (Enugu, Owerri and Onitsha) in the south-east region and to assess the performance of selected small- to medium-size commercial wind turbines. It is the authors' view that this information will be helpful to the government and any organization in making an informed decision with regard to investment in wind energy resource in this part of Nigeria.

\section{Methods}

The wind data used in this study were obtained from the Nigerian Meteorological Agency, Oshodi, Lagos. The geographical coordinates of the meteorological stations where the wind speed data were captured at a height of $10 \mathrm{~m}$ by a cup-generator anemometer are given in Table 1. There are many sources of measurement uncertainty in cup-anemometer measurements. The guidelines and steps necessary to minimize these errors are outlined in Manwell et al. [10]. Following the methodologies proposed and explained in the ISO guide [11] to the expression of uncertainty in measurement, the uncertainty in the mean velocities at $95 \%$ confidence level was determined to be $\pm 2 \%$. Monthly wind data that span between 24 and 37 years were obtained for Enugu, Owerri and Onitsha. The recorded wind speeds were computed as the mean of the speed for each month. It should be noted that using monthly wind speed has some limitations such as loosing extremely low or high wind speeds within the month as well as inability to observe diurnal variations in the wind speed. However, using monthly mean wind speed, which is mostly available for most locations, can be used to study the seasonal changes in wind speed and facilitates wind data analysis.

Table 1 The geographical location of the selected stations

\begin{tabular}{lllll}
\hline \multicolumn{4}{l}{ Station Latitude (N) Longitude (E) } & Altitude (m) Measurement period \\
\hline Enugu & $6^{\circ} 26^{\prime}$ & $7^{\circ} 29^{\prime}$ & 304.70 & 1971 to 2007 \\
Owerri & $5^{\circ} 29^{\prime}$ & $7^{\circ} 02^{\prime}$ & 186.05 & 1977 to 2002 \\
Onitsha & $6^{\circ} 10^{\prime}$ & $6^{\circ} 47^{\prime}$ & 63.14 & 1978 to 2003 \\
\hline
\end{tabular}

$\mathrm{N}$, North; E, East.

\section{Frequency distribution and site wind speed parameters}

Several mathematical models such as normal and lognormal have been used for wind data analysis. Prior studies have also shown that statistical methods such as the Weibull and Rayleigh distribution models can equally be used [12]. According to [13-15], the two-parameter Weibull probability distribution function is the most appropriate, accepted and recommended distribution function for wind speed data analysis. This is because it gives a better fit for measured monthly probability density distributions than other statistical functions [12,15]. In addition, the Weibull parameters at known height can be used to estimate wind parameters at another height [13]. Therefore, the two-parameter Weibull probability density function was used in this study. In Weibull distribution, the variation in wind velocity is characterized by two parameter functions: the probability density function and the cumulative distribution. The probability density function $f(V)$ indicates the probability of the wind at a given velocity $V$, while the corresponding cumulative distribution function of the velocity $V$ gives the probability that the wind velocity is equal to or lower than $V$, or within a given wind speed range. The Weibull probability density function is given as, e.g., $[12,16]$ :

$$
f(V)=\left(\frac{k}{c}\right)\left(\frac{V}{c}\right)^{k-1} \exp \left[-\left(\frac{V}{c}\right)^{k}\right]
$$

where $f(V)=$ the probability of observing wind speed $(V), k=$ dimensionless Weibull parameter and $c=$ the Weibull scale parameter (in meter per second). The scale factor could be related to the mean wind speed through the shape factor, which determines the uniformity of the wind speed in a given site. The cumulative distribution $F$ $(V)$ is the integral of the probability density function, and it is expressed as, e.g., $[12,16]$ :

$$
F(V)=1-e^{-(V / c)^{k}}
$$

The monthly and annual values of Weibull parameters were calculated using standard deviation method. This method is useful where only the mean wind speed and standard deviation are available. In addition, it gives better results than graphical method and has relatively simple expressions when compared with other methods $[13,17,18]$. Moreover, it is unlike most of the other methods that may require more detailed wind data (which, in some cases, are not readily available) for the determination of the Weibull distribution shape and scale parameters. The shape and scale factors are thus 
computed from Equations 3 and 4 given by $[13,19]$ :

$$
\begin{aligned}
& k=\left(\frac{\sigma}{V_{\mathrm{m}}}\right)^{-1.086} \\
& c=\frac{V_{\mathrm{m}}}{\Gamma\left(1+\frac{1}{k}\right)}
\end{aligned}
$$

where $\sigma$ is the standard deviation, $V_{\mathrm{m}}$ is the mean wind speed (in meter per second) and $\Gamma^{\prime}(x)$ is the gamma function, which is defined as $[17,19]$ :

$$
\Gamma(x)=\int_{0}^{\infty} t^{x-1} e^{-t} d t .
$$

Alternatively, scale factor can be determined from the following expressions given by [20]:

$$
c=\frac{V_{\mathrm{m}} k^{2.6674}}{0.184+0.816 k^{2.73855}}
$$

Equation 6 is used in this study to estimate the monthly and annual scale factors.

In addition to the mean wind speed, the other two significant wind speeds for wind energy estimation are the most probable wind speed $\left(V_{\mathrm{F}}\right)$ and the wind speed carrying maximum energy $\left(V_{\mathrm{E}}\right)$. They can be expressed respectively as [12,21]:

$$
\begin{aligned}
& V_{\mathrm{F}}=c\left(\frac{k-1}{k}\right)^{1 / k} \\
& V_{\mathrm{E}}=c\left(\frac{k+2}{k}\right)^{1 / k}
\end{aligned}
$$

The most probable wind speed corresponds to the peak of the probability density function, while the wind speed carrying maximum energy can be used to estimate the wind turbine design or rated wind speed. Prior studies have shown that wind turbine system operates most efficiently at its rated wind speed. Therefore, it is required that the rated wind speed and the wind speed carrying maximum energy should be as close as possible [16].

\section{Extrapolation of wind speed at different hub height}

In most cases, the available wind data are measured at a height different from the wind turbine hub height. It is noted that it is the wind speed at the hub height that is of interest for wind power application; therefore, the available wind speeds are adjusted to the wind turbine hub height using the following power law expression, e.g., [12]:

$$
\frac{V}{V_{\mathrm{o}}}=\left(\frac{h}{h_{\mathrm{o}}}\right)^{\alpha}
$$

where $V$ is the wind speed at the hub height $h, V_{\mathrm{o}}$ is wind speed at the original height $h_{\mathrm{o}}$ and $\alpha$ is the surface roughness coefficient and is assumed to be 0.143 (or 1/7) in most cases. The surface roughness coefficient $\alpha$ can be determined from the following expression [22]:

$$
\alpha=\left[0.37-0.088 \ln \left(V_{\mathrm{o}}\right)\right] /\left[1-0.088 \ln \left(\frac{h_{\mathrm{o}}}{10}\right)\right]
$$

Alternatively, the Weibull probability density function can be used to obtain the extrapolated values of wind speed at different heights. Since the boundary layer development and the effect of the ground are non-linear with respect to wind speed, the scale factor $c$ and form factor $k$ of the Weibull distribution will change as a function of height by the following expressions [13]:

$$
\begin{aligned}
& c(h)=c_{\mathrm{o}}\left(\frac{h}{h_{\mathrm{o}}}\right)^{n} \\
& k(h)=k_{\mathrm{o}}\left[1-0.088 \ln \left(\frac{h_{\mathrm{o}}}{10}\right)\right] /\left[1-0.088 \ln \left(\frac{h}{10}\right)\right]
\end{aligned}
$$

where $c_{\mathrm{o}}$ and $k_{\mathrm{o}}$ are the scale factor and shape parameter, respectively, at the measurement height $h_{\mathrm{o}}$. The exponent $n$ is defined as:

$$
n=\left[0.37-0.088 \ln \left(c_{\mathrm{o}}\right)\right] /\left[1-0.088 \ln \left(\frac{h}{10}\right)\right]
$$

\section{Mean wind power density and energy density}

The mean wind power density can be estimated by using the following equation:

$$
P_{\mathrm{D}}=\frac{P(V)}{A}=\frac{1}{2} \rho V_{\mathrm{m}}^{3}
$$

where $P(V)=$ the wind power (in watt), $P_{\mathrm{D}}=$ the wind power density (watt per square meter), $\rho=$ the air density at the site (assumed to be $1.225 \mathrm{~kg} / \mathrm{m}^{3}$ in this study) and $A=$ the swept area of the rotor blades (in square meter). Both the mean wind speed and power density are generally used to classify the wind energy resource (e.g., Pacific Northwest Laboratory (PNL) wind power classification scheme, Illica et al. [23]). However, the wind power density (wind power per unit area) based on the Weibull probability density function can be calculated 
using the following equation [24]:

$$
P_{\mathrm{D}}=\frac{P(V)}{A}=\frac{1}{2} \rho c^{3} \Gamma\left(1+\frac{3}{k}\right)
$$

The mean energy density $\left(E_{\mathrm{D}}\right)$ over a period of time $T$ is the product of the mean power density and the time $T$, and it is expressed as:

$$
E_{\mathrm{D}}=\frac{1}{2} \rho c^{3} \Gamma\left(1+\frac{3}{k}\right) T
$$

\section{Wind turbine energy output and capacity factor}

A wind energy conversion system can operate at its maximum efficiency only if it is designed for a particular site because the rated power and cut-in and cut-off wind speeds must be defined based on the site wind characteristics [12]. It is essential that these parameters are selected so that energy output from the conversion system is maximized. The performance of a wind turbine installed in a given site can be examined by the amount of mean power output over a period of time $\left(P_{\mathrm{e}, \mathrm{ave}}\right)$ and the conversion efficiency or capacity factor of the turbine. The capacity factor $C_{\mathrm{f}}$ is defined as the ratio of the mean power output to the rated electrical power $\left(P_{\mathrm{eR}}\right)$ of the wind turbine $[12,20]$.

The mean power output $P_{\mathrm{e} \text {,ave }}$ and capacity factor $C_{\mathrm{f}}$ of a wind turbine can be estimated using the following expressions based on Weibull distribution function [12]:

$$
\begin{aligned}
& P_{\mathrm{e}, \mathrm{ave}}=P_{\mathrm{eR}}\left(\frac{e^{-\left(\frac{v_{\mathrm{c}}}{c}\right)^{k}}-e^{-\left(\frac{v_{\mathrm{r}}}{c}\right)^{k}}}{\left(\frac{v_{\mathrm{r}}}{c}\right)^{k}-\left(\frac{v_{\mathrm{c}}}{c}\right)^{k}}-e^{-\left(\frac{v_{\mathrm{f}}}{c}\right)^{k}}\right) \\
& C_{\mathrm{f}}=\frac{P_{\mathrm{e}, \mathrm{ave}}}{P_{\mathrm{eR}}}
\end{aligned}
$$

where $v_{\mathrm{c}}, v_{\mathrm{r}}$ and $v_{\mathrm{f}}$ are the cut-in wind speed, rated wind speed and cut-off wind speed, respectively. For an investment in wind power to be cost effective, it is suggested that the capacity factor should be greater than 0.25 [25].

\section{Wind-driven rotodynamic pumps}

There are three types of wind-powered pumping systems. They are the mechanical-piston pump, the mechanical-air lift (rotodynamic) pump and the electrical pump. In general, the volume of water produced by rotodynamic and electrical pumps are considered to be more than that of a piston pump at the same wind speed regime. This is because there is a better match between the rotodynamic and electrical pumps and the wind rotor than for a piston pump [26,27]. In this study, the performance of a rotodynamic pump is simulated. For a rotodynamic pump driven by a wind turbine with a given cut-in wind speed and a cut-out wind speed, the water produced over a period of time $T$ can be determined from:

$$
Q=T \int_{V_{\mathrm{i}}}^{V_{\mathrm{o}}} Q(V) f(V) d V
$$

where $Q(V)$ is the discharge of the pump at any wind speed, and it is given by [28]:

$$
Q(V)=\frac{1}{8} C_{\mathrm{P}} \eta V D\left(\frac{\rho_{\alpha}}{\rho_{\mathrm{w}}}\right)\left(\frac{V_{\mathrm{d}}^{2}}{g H}\right)\left(\frac{G \lambda_{\mathrm{D}}}{N_{\mathrm{PD}}}\right)
$$

where $V_{\mathrm{d}}$ is design wind speed, $G$ is the gear ratio, $N_{\mathrm{PD}}$ is the speed of the pump at design condition, $D$ is the wind turbine rotor diameter and $\lambda_{\mathrm{D}}$ is the design tip speed ratio of the wind turbine. For a water-pumping application, a tip speed ratio between 1 and 3 is recommended [10]. By substituting Equation 20 into Equation 19 and assuming Rayleigh probability density function $f(V)$, the total water produced over a given time is expressed as [26]:

$$
\begin{array}{r}
Q=\frac{\pi}{16 V_{m}^{2}} C_{\mathrm{P}_{\mathrm{D}}} \eta_{\mathrm{PD}} T D\left(\frac{\rho_{a}}{\rho_{w}}\right)\left(\frac{V_{d}^{2}}{g H}\right) \\
\left(\frac{G \lambda_{\mathrm{D}}}{N_{\mathrm{PD}}}\right) \int_{V_{\mathrm{i}}}^{V_{\mathrm{o}}} V^{2} \exp ^{-\left(\frac{\pi}{4}\left(\frac{V}{V_{\mathrm{m}}}\right)^{2}\right)} d V
\end{array}
$$

\section{Results and discussion}

\section{Wind speed frequency distribution}

The annual probability density frequency and cumulative distributions of wind speed for the three locations obtained using the Weibull distribution function are shown in Figure 1. The probability density function is used to illustrate the fraction of time for which given wind speed possibly prevails at a location. As expected, the peak of the density function frequencies of all the sites skewed towards the higher values of mean wind speed (Figure 1a). It should be remarked that the peak of the probability density function curve indicates the most frequent velocity. It can be observed from Figure 1a that the most frequent wind speed expected in Enugu, Owerri and Onitsha are about 5.5, 3.5 and $3.5 \mathrm{~m} / \mathrm{s}$, respectively. It can be further observed that Enugu has the highest spread of wind speed toward high wind speed among the locations.

The cumulative probability distributions of the wind speed at all the study locations (Figure 1b) show a similar trend. The cumulative distribution function can be used for estimating the time for which wind speed is within a certain speed interval. For wind speeds greater or equal to $2.5 \mathrm{~m} / \mathrm{s}$ cut-in wind speed, Enugu, Owerri and Onitsha have frequencies of about $96.9 \%, 86.5 \%$ and 


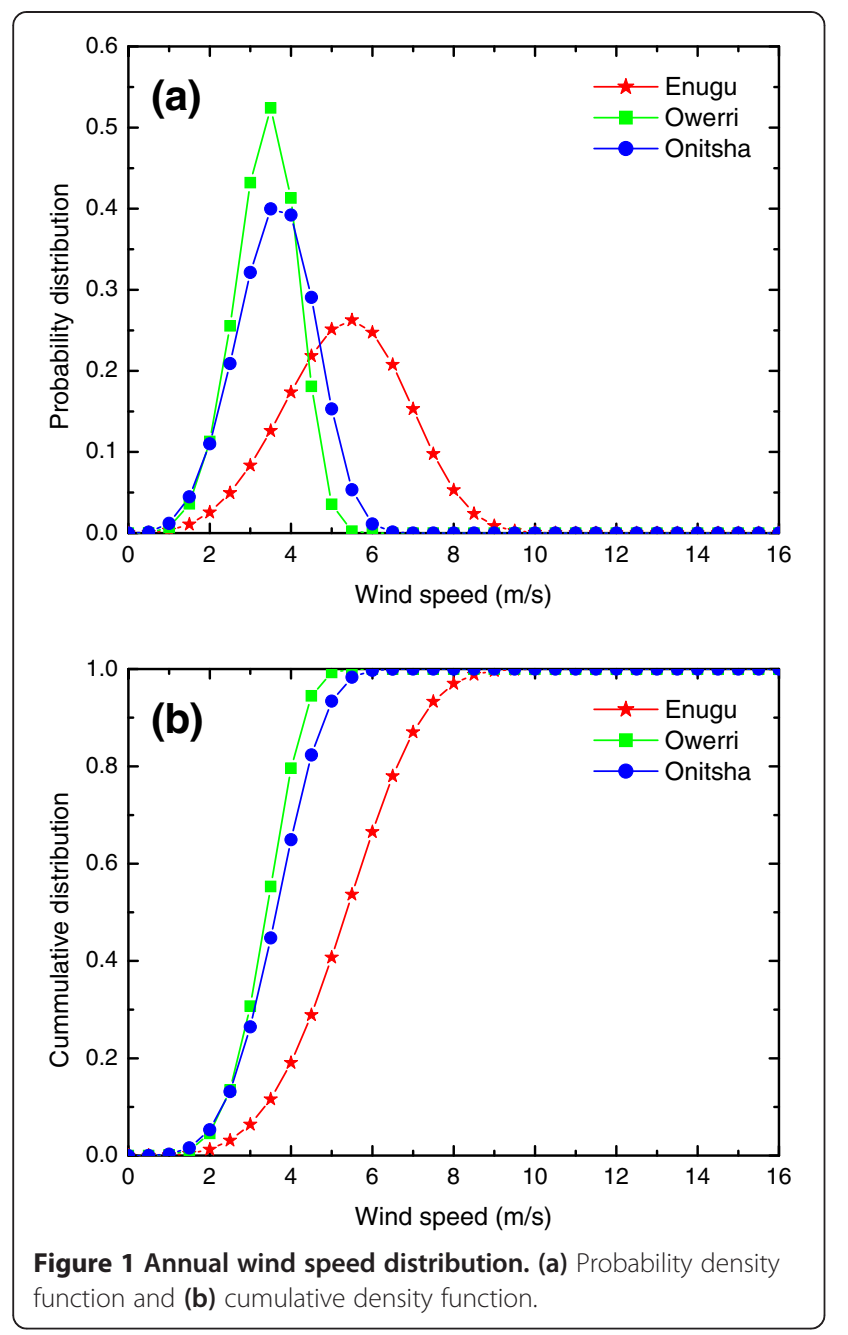

$86.9 \%$, respectively, while the same locations respectively have frequencies of about $88.4 \%, 44.7 \%$ and $55.3 \%$ for wind speed of $3.5 \mathrm{~m} / \mathrm{s}$ cut-in wind speed. According to Ojosu and Salawu [3], if a wind turbine system with a design cut-in wind speed of $2.2 \mathrm{~m} / \mathrm{s}$ is used in these sites for wind energy resource for electricity generation, all the sites will have frequencies of more than $92 \%$.

\section{Mean wind speed and mean power density}

The monthly variation of the mean wind speed characteristics $\left(V_{\mathrm{m}}, V_{\mathrm{F}}\right.$ and $\left.\mathrm{V}_{\mathrm{E}}\right)$, mean power density and mean energy density as well as the annual values of these parameters at a height of $10 \mathrm{~m}$ are presented in Tables 2, 3 and 4 .

The monthly mean wind speed varies between $4.13 \mathrm{~m} / \mathrm{s}$ in November and $6.30 \mathrm{~m} / \mathrm{s}$ in March for Enugu site (Table 2). The monthly mean power density varies between $43.15 \mathrm{~W} / \mathrm{m}^{2}$ in November and $153.16 \mathrm{~W} / \mathrm{m}^{2}$ in March. Therefore, based on PNL wind power classification scheme [23], the monthly mean power density mostly falls into class $1\left(P_{\mathrm{D}} \leq 100\right)$ except in January, February, April
Table 2 Characteristic speeds and mean power density in Enugu at a height of $10 \mathrm{~m}$

\begin{tabular}{|c|c|c|c|c|c|c|c|}
\hline & $V_{m}(\mathrm{~m} / \mathrm{s})$ & $k$ & $c(\mathrm{~m} / \mathrm{s}$ & $V_{F}(\mathrm{~m} / \mathrm{s}$ & $E(\mathrm{~m} / \mathrm{s})$ & $P_{\mathrm{D}}\left(\mathrm{W} / \mathrm{m}^{2}\right)$ & $E_{D}\left(\mathrm{kWh} / \mathrm{m}^{2}\right)$ \\
\hline Jan & 5.62 & 3.49 & 6.25 & 5.68 & 7.12 & 108.72 & 78.279 \\
\hline Feb & 5.67 & 4.86 & 6.19 & 5.90 & 6.64 & 111.65 & 80.387 \\
\hline Mar & 6.30 & 5.75 & 6.81 & 6.58 & 7.17 & 153.15 & 110.271 \\
\hline Apr & 6.22 & 5.11 & 6.77 & 6.49 & 7.22 & 147.39 & 106.123 \\
\hline May & 5.35 & 4.44 & 5.87 & 5.54 & 6.39 & 93.79 & 67.530 \\
\hline Jun & 5.21 & 4.82 & 5.69 & 5.42 & 6.11 & 86.62 & 62.367 \\
\hline Jul & 5.48 & 5.45 & 5.94 & 5.72 & 6.29 & 100.80 & 72.574 \\
\hline Aug & 5.44 & 3.93 & 6.01 & 5.58 & 6.68 & 98.61 & 70.996 \\
\hline Sept & 4.85 & 4.79 & 5.30 & 5.04 & 5.70 & 69.88 & 50.311 \\
\hline Oct & 4.56 & 5.24 & 4.96 & 4.76 & 5.27 & 58.08 & 41.815 \\
\hline Nov & 4.13 & 3.75 & 4.58 & 4.22 & 5.13 & 43.15 & 31.066 \\
\hline Dec & 4.95 & 3.34 & 5.52 & 4.96 & 6.36 & 74.29 & 53.488 \\
\hline Annual & 5.42 & 4.05 & 5.87 & 5.47 & 6.48 & 96.98 & 717.619 \\
\hline
\end{tabular}

$V_{\mathrm{m}}$, mean wind speed; $k$, dimensionless Weibull shape parameter; $c$, Weibull scale parameter; $V_{F}$, most probable wind speed; $V_{E}$, wind speed carrying maximum energy; $P_{\mathrm{D}}$, wind power density; $E_{\mathrm{D}}$, mean energy density.

and July, when it falls into class $2\left(100<P_{\mathrm{D}} \leq 150\right)$, and in March, when it falls into class $3\left(150<P_{\mathrm{D}} \leq 200\right)$. However, the annual mean power density for this site is $96.98 \mathrm{~W} / \mathrm{m}^{2}$ (class 1 ). For Owerri (Table 3), the minimum and maximum values of the monthly mean wind speeds are 2.72 and $3.70 \mathrm{~m} / \mathrm{s}$, respectively, while the annual mean wind speed for this site is $3.36 \mathrm{~m} / \mathrm{s}$. The monthly mean power density varies between $11.66 \mathrm{~W} / \mathrm{m}^{2}$ in November and $31.02 \mathrm{~W} / \mathrm{m}^{2}$ in January. The monthly mean power density falls into class 1 wind resource category $\left(P_{\mathrm{D}} \leq 100\right)$

Table 3 Characteristic speeds and mean power density in Owerri at a height of $10 \mathrm{~m}$

\begin{tabular}{|c|c|c|c|c|c|c|c|}
\hline & $V_{\mathrm{m}}(\mathrm{m} / \mathrm{s})$ & $k$ & $c(\mathrm{~m} / \mathrm{s})$ & $V_{F}(\mathrm{~m} / \mathrm{s})$ & $V_{E}(\mathrm{~m} / \mathrm{s})$ & $P_{D}\left(\mathrm{~W} / \mathrm{m}^{2}\right)$ & $E_{D}\left(\mathrm{kWh} / \mathrm{m}^{2}\right)$ \\
\hline Jan & 3.52 & 2.61 & 3.96 & 3.29 & 4.92 & 26.71 & 19.234 \\
\hline Feb & 3.54 & 8.11 & 3.74 & 3.68 & 3.84 & 27.17 & 19.564 \\
\hline Mar & 3.64 & 7.00 & 3.87 & 3.79 & 4.02 & 29.54 & 21.269 \\
\hline Apr & 3.70 & 6.61 & 3.96 & 3.87 & 4.12 & 31.02 & 22.338 \\
\hline May & 3.45 & 8.48 & 3.63 & 3.58 & 3.72 & 25.15 & 18.109 \\
\hline Jun & 3.55 & 8.46 & 3.74 & 3.68 & 3.83 & 27.40 & 19.730 \\
\hline Jul & 3.32 & 6.30 & 3.56 & 3.47 & 3.72 & 22.41 & 16.138 \\
\hline Aug & 3.42 & 5.30 & 3.72 & 3.57 & 3.95 & 24.50 & 17.641 \\
\hline Sept & 3.31 & 7.01 & 3.53 & 3.45 & 3.66 & 22.21 & 15.993 \\
\hline Oct & 3.04 & 5.41 & 3.30 & 3.17 & 3.49 & 17.21 & 12.390 \\
\hline Nov & 2.67 & 6.28 & 2.97 & 2.88 & 3.10 & 11.66 & 8.394 \\
\hline Dec & 3.00 & 4.80 & 3.28 & 3.12 & 3.53 & 16.54 & 11.907 \\
\hline Annual & 3.36 & 5.10 & 3.65 & 3.50 & 3.90 & 23.23 & 203.530 \\
\hline
\end{tabular}

$V_{\mathrm{m}}$, mean wind speed; $k$, dimensionless Weibull shape parameter; $c$, Weibull scale parameter; $V_{F}$, most probable wind speed; $V_{E}$, wind speed carrying maximum energy; $P_{\mathrm{D}}$, wind power density; $E_{\mathrm{D}}$, mean energy density. 
Table 4 Characteristic speeds and mean power density in Onitsha at a height of $10 \mathrm{~m}$

\begin{tabular}{|c|c|c|c|c|c|c|c|}
\hline & $V_{\mathrm{m}}(\mathrm{m} / \mathrm{s})$ & $k$ & $c(\mathrm{~m} / \mathrm{s})$ & $V_{\mathrm{F}}(\mathrm{m} / \mathrm{s})$ & $V_{E}(\mathrm{~m} / \mathrm{s})$ & $P_{\mathrm{D}}\left(\mathrm{W} / \mathrm{m}^{2}\right)$ & $E_{\mathrm{D}}\left(\mathrm{kWh} / \mathrm{m}^{2}\right)$ \\
\hline Jan & 3.59 & 4.91 & 3.92 & 3.74 & 4.20 & 28.34 & 20.404 \\
\hline Feb & 3.73 & 4.11 & 4.11 & 3.84 & 4.53 & 31.79 & 22.886 \\
\hline Mar & 4.23 & 4.86 & 4.62 & 4.41 & 4.96 & 46.36 & 33.378 \\
\hline Apr & 4.07 & 5.00 & 4.44 & 4.24 & 4.75 & 41.29 & 29.732 \\
\hline May & 3.76 & 4.71 & 4.11 & 3.91 & 4.43 & 32.56 & 23.442 \\
\hline Jun & 3.72 & 4.55 & 4.08 & 3.86 & 4.42 & 31.53 & 22.702 \\
\hline Jul & 3.58 & 4.51 & 3.92 & 3.71 & 4.26 & 28.10 & 20.234 \\
\hline Aug & 3.61 & 4.77 & 3.95 & 3.76 & 4.25 & 28.82 & 20.747 \\
\hline Sept & 3.52 & 4.74 & 3.85 & 3.66 & 4.15 & 26.71 & 19.234 \\
\hline Oct & 3.28 & 4.23 & 3.60 & 3.37 & 3.94 & 21.61 & 15.562 \\
\hline Nov & 3.01 & 4.78 & 3.29 & 3.13 & 3.54 & 16.70 & 12.026 \\
\hline Dec & 3.05 & 3.52 & 3.39 & 3.08 & 3.85 & 17.38 & 12.512 \\
\hline Annual & 3.59 & 4.27 & 3.96 & 3.72 & 4.33 & 28.34 & 248.252 \\
\hline
\end{tabular}

$V_{m}$, mean wind speed; $k$, dimensionless Weibull shape parameter; $c$, Weibull scale parameter; $V_{F}$, most probable wind speed; $V_{E}$, wind speed carrying maximum energy; $P_{\mathrm{D}}$, mean wind power density; $E_{\mathrm{D}}$, mean energy density.

in all the months, and the annual mean power density for this site is $23.23 \mathrm{~W} / \mathrm{m}^{2}$ (class 1 ). In the case of Onitsha (Table 4), the minimum and maximum values of the monthly mean wind speeds are $3.01 \mathrm{~m} / \mathrm{s}$ (in November) and $4.23 \mathrm{~m} / \mathrm{s}$ (in March), respectively. The monthly mean power density varies between $16.70 \mathrm{~W} / \mathrm{m}^{2}$ in November and $46.36 \mathrm{~W} / \mathrm{m}^{2}$ in March. The monthly mean power density falls into class 1 wind resource category $\left(P_{\mathrm{D}} \leq 100\right)$ in all the months, and the annual mean power density for this site is $28.34 \mathrm{~W} / \mathrm{m}^{2}$ (class 1). Detailed information about these sites' wind speed characteristics (mean wind speed, most probable wind speed $\left(V_{\mathrm{F}}\right)$ and the wind speed carrying maximum energy $\left.\left(V_{\mathrm{E}}\right)\right)$ and mean power density are illustrated in Tables 2, 3 and 4.

The least monthly value of the Weibull shape parameter $k$ for Owerri is 2.61 in January and reached the highest value of 8.48 in the month of May. Therefore, the wind speed is most uniform in Owerri in May, while it is least uniform in December. The annual shape factors for Enugu, Owerri and Onitsha are 4.05, 5.10 and 4.27, respectively. The least monthly value of Weibull scale parameter $c$ is obtained as $2.97 \mathrm{~m} / \mathrm{s}$ in the month of November in Owerri, and the highest value of $6.81 \mathrm{~m} / \mathrm{s}$ in the month of March in Enugu. The annual shape factors for Enugu, Owerri and Onitsha are 5.87, 3.65 and $3.96 \mathrm{~m} / \mathrm{s}$, respectively.

In summary, Enugu has the highest annual mean wind speed among the sites considered in this study. Also, this site has the highest values of annual power density. Even though the most probable wind speed $\left(V_{\mathrm{F}}\right)$ is a statistical characteristic, which may not be directly connected to wind energy [21], it does not necessarily mean that
Enugu has much higher wind potentials than the other locations considered. However, as mentioned earlier, the efficiency of a wind turbine is closely related to these parameters, especially $V_{\mathrm{E}}$, which should be as close as possible to the design or rated wind speed of the system. Therefore, the proposed wind turbine, if installed in Enugu, would likely produce more power than other locations. Moreover, it can be considered as the best site for wind energy development in southern Nigeria (based on the three sites considered in this study). Furthermore, the monthly mean wind speeds in south Nigeria ranges from 2.72 to $6.30 \mathrm{~m} / \mathrm{s}$. The monthly mean power density varies between 11.66 and $153.15 \mathrm{~W} / \mathrm{m}^{2}$, while the annual mean power density is in the range of 23.23 to $96.98 \mathrm{~W} / \mathrm{m}^{2}$. It can be inferred from this analysis that the wind resource in this part of Nigeria can be classified mostly into class 2 or less category. Furthermore, the annual mean energy density varies between 203.53 and $717.62 \mathrm{kWh} / \mathrm{m}^{2}$.

Even though the wind resource in these locations falls into class 2 or less, which is considered as marginally or unsuitable for wind power development, the wind power can be used for water pumping and small-scale electricity generation, providing intermittent power requirements for a variety of purposes that need low-energy capacity, slow-running high-torque wind turbines with multi-blade, e.g., $[3,4,6,29]$. For a modern wind turbine, the cut-in wind speed required by it to start generating electricity is generally between 3 to $5 \mathrm{~m} / \mathrm{s}$. Depending on the size of the turbine, the peak power output can be attained when the wind speed (rated wind speed) is in the range of 10 to $15 \mathrm{~m} / \mathrm{s}$ [6]. For water pumping, wind turbine can be operated at a lower wind speed; however, they can function effectively when the wind speed is more than $3 \mathrm{~m} / \mathrm{s}$. Based on the required quantity of water, a site with a mean wind speed around $2.0 \mathrm{~m} / \mathrm{s}$ can be considered for wind-powered pump application [30]. Similarly, depending on the end use of the generated power, it can be concluded that these locations may be suitable for utilization of wind energy.

\section{Performance of selected wind turbines}

Seven small- to medium-size commercial wind turbine models with rated power range from 50 to $1,000 \mathrm{~kW}$ [31-33] were selected to simulate their performance at Enugu, Owerri and Onitsha. These are P15-50, P19-100, P50-500 and P62-1000 models (Polaris America LLC, Lakewood, NJ, USA ); WES30 model (Wind Energy Solutions BV, The Netherlands); WWD-1-60 model (Winwind, Espoo, Finland) and BONUS 1000-54 (Siemens AG, Erlangen, Germany). The selected wind turbine models and their characteristic properties are given in Table 5. For each location, the annual energy output and capacity factor based on Weibull distribution 
Table 5 Characteristics of the selected wind turbines

\begin{tabular}{|c|c|c|c|c|c|c|c|}
\hline & POLARIS P15-50 & POLARIS P19-100 & WES30 & POLARIS P50-500 & POLARIS P62-1000 & WWD-1-60 & BONUS-1000-54 \\
\hline Rated power (kW) & 50 & 100 & 250 & 500 & 1,000 & 1,000 & 1,000 \\
\hline Hub height (m) & 30 & 30 & 36 & 50 & 60 & 70 & 45 \\
\hline Rotor diameter (m) & 15.2 & 19.1 & 30 & 50 & 62 & 60 & 54 \\
\hline Cut-in wind speed $(\mathrm{m} / \mathrm{s})$ & 2.5 & 2.5 & 2.7 & 2.5 & 2.5 & 3.6 & 3 \\
\hline Rated wind speed $(\mathrm{m} / \mathrm{s})$ & 10 & 12 & 12.5 & 12 & 12 & 12.5 & 14 \\
\hline Cut-out wind speed $(\mathrm{m} / \mathrm{s})$ & 25 & 25 & 25 & 25 & 25 & 25 & 25 \\
\hline
\end{tabular}

[12,31-33].

function parameters at their respective hub height are determined using Equations 17 and 18, respectively.

The performance of the selected wind turbine models at all the locations is presented in Figure 2. The figure clearly reveals that irrespective of the wind turbine model, Enugu seems to be the best site for wind power development for electricity generation. This is expected because, when compared with other sites, Enugu has the highest annual mean wind speed and highest value of $V_{\mathrm{E}}$ at the hub height for each turbine. The annual energy output for Enugu ranges from about $113 \mathrm{MWh} /$ year using POLARIS 19-100 model to 2,444 MWh using WWD-1-60 model. Among the 1,000-kW model turbines, the WWD-1-60 model produced the highest power output, closely followed by the POLARIS 62-1000 (2,431 MWh/year), while BONUS 1000-54 produced the least power ( $849 \mathrm{MWh} /$ year). This observed trend is related to the hub height and rotor diameter (which are lowest for the BONUS model), the design or rated wind speed (highest for the BONUS model, $14 \mathrm{~m} / \mathrm{s}$ ) and the cut-in wind speed (highest for the WWD-1-60 model, $3.6 \mathrm{~m} / \mathrm{s}$ ). Even though the hub height of the WWD-1-60 model is higher than that of the POLARIS 62 model, the POLARIS 62 model still produced almost the same amount of power $(2,431 \mathrm{MWh} /$ year $)$ due to its lower cut-in wind speed and rated wind speed. Furthermore, it is observed that the energy output from the POLARIS 15-50 model is slightly more than the power output from the POLARIS 19-100 model. This is because both models have the same hub height, and the POLARIS 19-100 model has higher rated wind speed than the POLARIS 15-50 model.

The minimum annual energy outputs of 6.05 and 18.83 MWh/year are observed for Owerri and Onitsha, respectively, using the P19-100 model. While the maximum annual energy outputs are 178.58 and 461.32 MWh/year, respectively, for Owerri and Onitsha with the WWD-1-60 model. For each of these sites, the power generated by each wind turbine follows the same trend observed in Enugu. Regardless of the location, the WWD-1-60 wind turbine model produced the highest quantity of annual energy output. For example, if 1,000$\mathrm{kW}$ turbines are to be operated at the same hub height, the POLARIS 62-1000 will likely perform better than WWD-1-60 and BONUS-1000-54 because of its low cutin wind speed and rated wind speed as well as its bigger rotor diameter compared with other models.

The cost effectiveness of a wind turbine can be roughly estimated by the capacity factor of the turbine. This factor is a useful parameter for both consumer and manufacturer of the wind turbine system [24]. The WWD-1-60 model
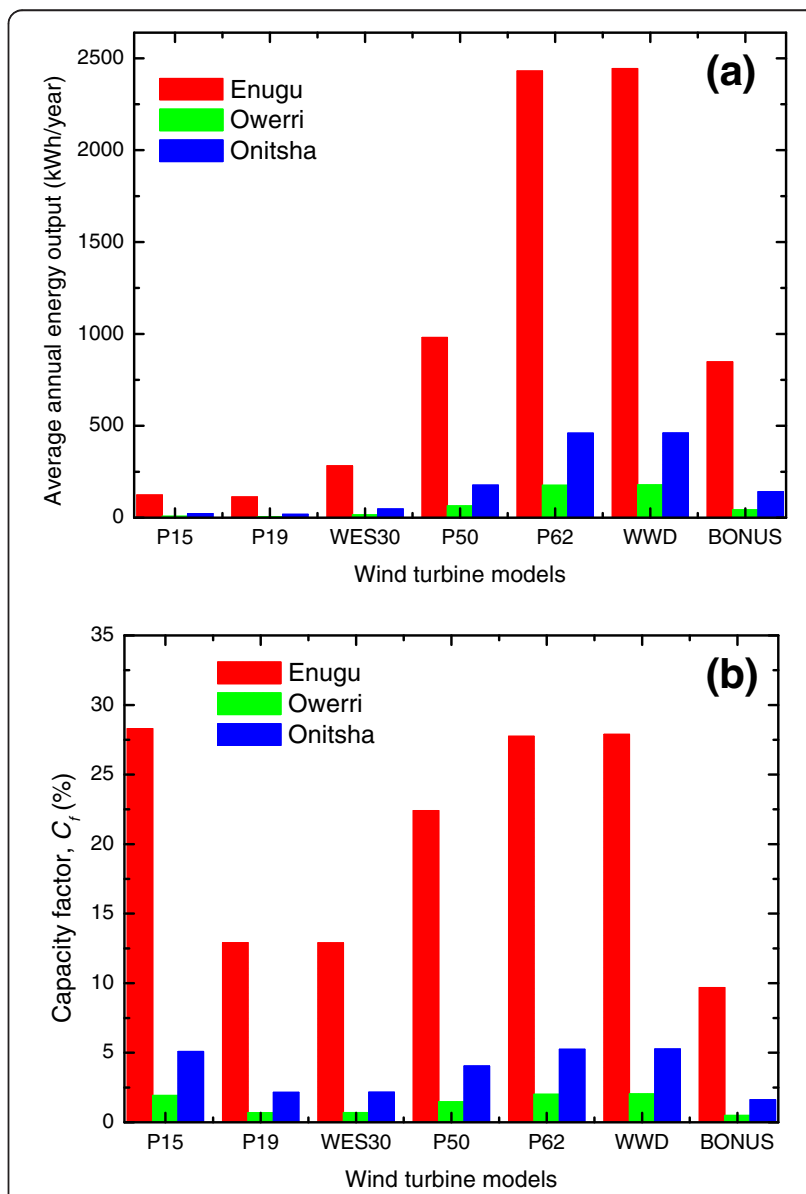

Figure 2 The performance of the selected wind turbine models for all the locations. (a) Average annual energy output and (b) capacity factor. 
has the highest value among the models considered for all the sites. The $C_{\mathrm{f}}$ values for this model are $27.90 \%, 2.04 \%$ and $5.27 \%$ for Enugu, Owerri and Onitsha, respectively. The $C_{\mathrm{f}}$ values for Enugu for POLARIS 15-50, POLARIS 62-1000 and WWD-1-60 are 28.30\%, 27.75\% and 27.90\%, respectively. These values are greater than the suggested recommended value before an investment can be considered worthwhile. Hence, these wind turbines or similar turbine model will be good for electricity generation in Enugu. In Owerri, however, the capacity factor for other wind turbine models ranges from $0.49 \%$ for the BONUS-1000-54 model to $2.04 \%$ for the WWD-1-60 model. Similarly, the minimum and maximum capacity factors at Onitsha are $1.62 \%$ for the BONUS-1000-54 model and $5.27 \%$ for the WWD-1-60 model, respectively. Therefore, these two sites may be considered for wind energy development for smallscale applications such as water pumping (see 'Wind-powered pumps performance'). It should be noted that the cost of generating electricity using wind turbine is inversely proportional to the capacity factor. The higher the capacity factor (or higher wind speed regime), the lower the cost of generated electricity, assuming that all factors remain the same (see, e.g., Paul et al. [34]).

Based on the annual energy output and the capacity factor, the POLARIS 62-1000 and WWD-1-60 models or wind turbines with similar designed characteristics will be best suited for electricity generation at Enugu and smallscale application in other locations. However, by redesigning the selected wind turbine models to operate at lower cut-in wind speed (especially the WWD-1-60 and BONUS-100-54 models), lower rated wind speed (especially BONUS-100-54) and higher hub height compared with their current design parameters (cut-in and rated wind speeds and hub height), both the annual energy output and capacity factor could significantly be improved. For instance, if POLARIS $62-1000$ is to be operated at a hub height of $70 \mathrm{~m}$ and rated wind speed of $10 \mathrm{~m} / \mathrm{s}$, the capacity factor for Enugu, Owerri and Onitsha will be $59.17 \%, 8.20 \%$ and $16.99 \%$, respectively. However, increasing the hub height may increase the overall capital cost of the wind turbines. But this is compensated for by increased in capacity factor and, hence, the energy output from the wind turbines.

In order to meet the minimum recommended capacity factor (25\%) for electricity generation, the following design parameters are suggested: wind turbine model with a minimum hub height of $55 \mathrm{~m}$, cut-in wind speed of less than $3.5 \mathrm{~m} / \mathrm{s}$, rated wind speed of around $12 \mathrm{~m} / \mathrm{s}$ and cut-out wind speed of $25 \mathrm{~m} / \mathrm{s}$ are recommended for Enugu; for Owerri, wind turbine with a minimum height of $75 \mathrm{~m}$, cutin wind speed of less than $3.5 \mathrm{~m} / \mathrm{s}$, rated wind speed of around $8.5 \mathrm{~m} / \mathrm{s}$ and cut-out wind speed of $20 \mathrm{~m} / \mathrm{s}$ are recommended; while a system with a minimum hub height of $65 \mathrm{~m}$, cut-in wind speed of less than $3.5 \mathrm{~m} / \mathrm{s}$, rated wind speed of around $9 \mathrm{~m} / \mathrm{s}$ and cut-out wind speed of $20 \mathrm{~m} / \mathrm{s}$ are recommended for Onitsha.

\section{Wind-powered pumps performance}

In this section, the performance of wind-powered pumps assumed to be located in each of the locations considered in this study is presented and discussed. For the performance assessment, a wind turbine model with a rated power of about $0.36 \mathrm{~kW}$ is chosen. The characteristic properties of this wind turbine model and the specifications of the pumps are given in Table 6. The wind turbine characteristics are similar to the FT-2.5 wind turbine model (produced in China, according to [35]) [35,36] for water pumping. The hub height of the wind turbine is assumed to be $15 \mathrm{~m}$, which is within the hub height range for common commercial wind turbines for water-pumping application [30]. The pump head of $10 \mathrm{~m}$ is used for the analysis. This pump head was chosen because it is within the range of the water table level of 3 to $20 \mathrm{~m}$ in this part of Nigeria [37] and within the range of the design lifting height of 5 to $10 \mathrm{~m}$ for the FT-2.5 windmill [35]. The monthly mean wind speeds at hub height at each selected site are computed using Equations 9 and 10. The quantity of water pumped per month is computed using Equation 23. This equation was solved using Wind Energy Resource Analysis software developed by Mathew [25]. The software is based on Rayleigh distribution function and requires the mean wind speed, wind turbine and pump parameters as inputs.

The comparison between water produced per month by rotodynamic pump at the three locations is presented in Table 7. As expected from the wind speed frequency distribution, the amount of water output from the pump at Enugu is highest among the three locations. In Enugu, the monthly water output varies between about 3,136 and $3,512 \mathrm{~m}^{3}$, and the average volume discharge is about

\section{Table 6 Wind turbine parameters and rotodynamic pump specifications}

\begin{tabular}{lc}
\hline Parameters/specifications & Value \\
\hline Wind turbine & \\
Diameter $(\mathrm{m})$ & 2.5 \\
Rated power $(\mathrm{W})$ & 360 \\
Rated speed $(\mathrm{m} / \mathrm{s})$ & 7 \\
Cut-in speed $(\mathrm{m} / \mathrm{s})$ & 2.5 \\
Cut-out speed $(\mathrm{m} / \mathrm{s})$ & 10 \\
Design speed ratio & 2 \\
Design power coefficient & 0.35 \\
Pump & \\
Efficiency (pump and transmission) & 0.6 \\
Gear ratio & 10 \\
\hline
\end{tabular}


Table 7 Monthly water produced and the number of habitants that can be served per month

\begin{tabular}{|c|c|c|c|c|c|c|c|c|c|c|c|c|}
\hline \multirow[t]{2}{*}{ Month } & \multicolumn{4}{|c|}{ Enugu } & \multicolumn{4}{|c|}{ Owerri } & \multicolumn{4}{|c|}{ Onitsha } \\
\hline & $\begin{array}{c}V_{m} \\
(\mathrm{~m} / \mathrm{s})\end{array}$ & $\begin{array}{c}Q \\
\left(m^{3}\right)\end{array}$ & $\begin{array}{l}\text { Habitants } \\
50 \text { L/day }\end{array}$ & $\begin{array}{l}\text { Habitants } \\
36 \text { L/day }\end{array}$ & $\begin{array}{c}V_{\mathrm{m}} \\
(\mathrm{m} / \mathrm{s})\end{array}$ & $\begin{array}{c}Q \\
\left(m^{3}\right)\end{array}$ & $\begin{array}{l}\text { Habitants } \\
50 \text { L/day }\end{array}$ & $\begin{array}{c}\text { Habitants } \\
36 \text { L/day }\end{array}$ & $\begin{array}{c}V_{m} \\
(\mathrm{~m} / \mathrm{s})\end{array}$ & $\begin{array}{c}Q \\
\left(\mathrm{~m}^{3}\right)\end{array}$ & $\begin{array}{l}\text { Habitants } \\
50 \text { L/day }\end{array}$ & $\begin{array}{c}\text { Habitants } \\
36 \text { L/day }\end{array}$ \\
\hline Jan & 6.16 & $3,511.51$ & 2,341 & 3,251 & 3.92 & $2,687.47$ & 1,792 & 2,488 & 4.00 & $2,752.48$ & 1,835 & 2,549 \\
\hline Feb & 6.21 & $3,510.02$ & 2,340 & 3,250 & 3.95 & $2,710.74$ & 1,807 & 2,510 & 4.15 & $2,859.98$ & 1,907 & 2,648 \\
\hline Mar & 6.88 & $3,436.48$ & 2,291 & 3,182 & 4.05 & $2,787.89$ & 1,859 & 2,581 & 4.69 & $3,194.29$ & 2,130 & 2,958 \\
\hline Apr & 6.79 & $3,450.62$ & 2,300 & 3,195 & 4.12 & $2,843.95$ & 1,896 & 2,633 & 4.52 & $3,100.75$ & 2,067 & 2,871 \\
\hline May & 5.87 & $3,507.62$ & 2,338 & 3,248 & 3.85 & $2,633.46$ & 1,756 & 2,438 & 4.18 & $2,885.82$ & 1,924 & 2,672 \\
\hline Jun & 5.72 & $3,495.80$ & 2,331 & 3,237 & 3.96 & $2,721.07$ & 1,814 & 2,520 & 4.14 & $2,857.08$ & 1,905 & 2,645 \\
\hline Jul & 6.01 & $3,512.36$ & 2,342 & 3,252 & 3.71 & $2,510.67$ & 1,674 & 2,325 & 3.98 & $2,738.42$ & 1,826 & 2,536 \\
\hline Aug & 5.97 & $3,511.42$ & 2,341 & 3,251 & 3.82 & $2,605.90$ & 1,737 & 2,413 & 4.03 & $2,770.28$ & 1,847 & 2,565 \\
\hline Sept & 5.34 & $3,432.44$ & 2,288 & 3,178 & 3.70 & $2,502.78$ & 1,669 & 2,317 & 3.93 & $2,692.31$ & 1,795 & 2,493 \\
\hline Oct & 5.04 & $3,343.72$ & 2,229 & 3,096 & 3.41 & 2,232.75 & 1,489 & 2,067 & 3.65 & $2,460.31$ & 1,640 & 2,278 \\
\hline Nov & 4.58 & $3,136.10$ & 2,091 & 2,904 & 3.11 & $1,936.35$ & 1,291 & 1,793 & 3.38 & $2,205.90$ & 1,471 & 2,043 \\
\hline Dec & 5.45 & $3,456.25$ & 2,304 & 3,200 & 3.37 & $2,192.40$ & 1,462 & 2,030 & 3.42 & $2,240.39$ & 1,494 & 2,074 \\
\hline
\end{tabular}

Hub height is assumed as $15 \mathrm{~m} . V_{\mathrm{m}}$, the mean wind speed; $Q$, water produced at a given time.

$3,442 \mathrm{~m}^{3} /$ month. In Owerri, where the pump has the least performance among the three sites, the monthly water output varies between 1,936 and $2,844 \mathrm{~m}^{3}$ with an average discharge volume of about $2,530 \mathrm{~m}^{3} /$ month. In the case of Onitsha, the monthly water output varies between about 2,206 and $3,194 \mathrm{~m}^{3}$, and the average volume discharge is about $2,730 \mathrm{~m}^{3} /$ month. Therefore, all the sites have strong potential for wind energy development for water pumping. In fact, wind resource in these sites could also be used for electricity generation, as previously shown.

The total numbers of habitants that can be served by water discharged from these sites are also shown in Table 7. Based on water usage of $36 \mathrm{~L} /$ capita/day in Nigeria as of 2006 [38], the water output at Enugu can serve between 2,900 and 3,250 habitants depending on the month. The average number of people that can be served per month is estimated to be around 3,190. However, if the estimate is based on the minimum recommended water usage of $50 \mathrm{~L} /$ capita/day [38], the water produced can only serve about 2,290 habitants per month on average. In Owerri, the water produced can serve about 2,340 and 1,690 habitants per month on average based on 36 and 50 L/capita/day, respectively, while the total numbers of habitants that can be served by the water produced in Onitsha are 2,530 and $1,820 /$ month on average based on water usage of 36 and $50 \mathrm{~L} /$ capita/day, respectively. Therefore, for small rural communities scattered across the southeastern part of $\mathrm{Ni}$ geria where access to good water and unreliable supply of water is a regular problem, wind resource development for water pumping will be a good option. For a larger community, the performance of a pump can be increased if a wind turbine with higher rated power (or diameter) is used instead of the small size used in this study. In addition, two or more wind turbines can be installed in these sites in order to increase the quantity of water produced.

\section{Conclusions}

In this study, the wind speed and wind energy potential in selected three locations in the southeastern part of $\mathrm{Ni}$ geria were investigated. In addition, the performance of selected commercial wind turbine models designed for both electricity generation and water pumping located in these sites was investigated. The findings from this study can be summarized as follows:

1. The annual mean wind speeds for Enugu, Owerri and Onitsha are 5.42, 3.36 and $3.59 \mathrm{~m} / \mathrm{s}$, respectively. The annual values of the wind speed carrying maximum energy for these locations are respectively $6.48,4.33$ and $3.90 \mathrm{~m} / \mathrm{s}$.

2. The mean annual value of Weibull shape parameter $k$ is between 4.05 and 5.10, while the annual value of scale parameter $c$ is between 3.96 and $5.87 \mathrm{~m} / \mathrm{s}$.

3. The annual mean power density for Enugu, Owerri and Onitsha are 96.98, 23.23 and $28.34 \mathrm{~W} / \mathrm{m}^{2}$, respectively. Therefore, based on the wind data used in this study, the wind energy resource in south-east Nigeria may generally be classified into class 1 .

However, based on monthly mean power density, the wind resource may fall into higher class category in some cases.

4. Based on the capacity factor, the POLARIS 15-50, POLARIS 62-1000 and WWD-1-60 models or wind turbines with similar designed characteristics will be best suited for electricity generation in Enugu. However, in order to meet the minimum 
recommended capacity factor (25\%) for electricity generation, wind turbine models with cut-in wind speed of less than $3.5 \mathrm{~m} / \mathrm{s}$ minimum and hub height of 55,75 and $65 \mathrm{~m}$, as well as rated wind speed of about $12,8.5$ and $9 \mathrm{~m} / \mathrm{s}$, respectively, are recommended for Enugu, Owerri and Onitsha.

5. Using a $0.36-\mathrm{kW}$ wind turbine, the average monthly water produced by a rotodynamic pump assumed to be installed in Enugu, Owerri and Onitsha is determined as 3,442, 2,530 and 2,730 $\mathrm{m}^{3}$, respectively. The quantity of water can serve about 2,290, 1,690 and 1,820 habitants in respective locations.

\begin{abstract}
Abbreviations
$A$ : wind power rotor swept area; $c$ : Weibull scale parameter; $C_{f}$ : capacity factor; $C_{0}$ : scale factor at the height $h_{0} ; C_{p}$ : wind turbine power coefficient; $C_{\mathrm{PD}}$ : wind turbine design power coefficient; $D$ : wind turbine rotor diameter; $E_{D}$ : mean energy density; $f(V)$ : probability of observing wind speed $(V) ; F$ (V): cumulative of observing wind speed ( $V$; $G$ : pump gear ratio; $g$ : acceleration due to gravity; $\mathrm{H}$ : water head; $\mathrm{H}$ : wind turbine hub height; $h_{0}$ : cup-generator anemometer height; $k$ : dimensionless Weibull shape parameter; $k_{\mathrm{o}}$ : shape parameter height $h_{\mathrm{o}} ; N_{\mathrm{PD}}$ : pump speed at design condition; $n$ : exponent; $P_{\mathrm{D}}$ : mean wind power density; $P_{\text {eave: }}$ : mean power output; $P_{\mathrm{eR}}$ : rated wind turbine power; $P(V)$ : wind power; $Q$ : water produced at a given time; $Q(V)$ : volume discharge of the pump at any wind speed $V$; $T$ : period or time; $V$ : wind speed; $V_{E}$ : wind speed carrying maximum energy; $V_{F}$ : most probable wind speed; $V_{m}$ : mean wind speed; $V_{0}$ : wind speed at the cup-generator anemometer height; $v_{c}$ : cut-in wind speed; $V_{d}: v_{r}$, rated wind speed; $v_{f}$ : cut-off wind speed.
\end{abstract}

\section{Symbols}

$a$, surface roughness coefficient; $\sigma$, standard deviation; $\Gamma(x)$, gamma function; $\lambda D$, design tipspeed ratio of the wind turbine; $\rho$, air density; $\rho_{w}$, water density; $\eta$, overall pump efficiency; $\eta_{P D}$, overall design pump efficiency.

\section{Competing interests}

The authors declare that they have no competing interests.

\section{Acknowledgments}

The authors are grateful to the Nigerian Meteorological Agency (NIMET), Oshodi, Lagos, Nigeria, for providing data for this study.

\section{Author details \\ ${ }^{1}$ Mechanical Engineering Department, Covenant University, Ota, Ogun State 112101, Nigeria. ${ }^{2}$ Department of Energy and Process Engineering, Norwegian University of Science and Technology, Trondheim, NO-7491, Norway. ${ }^{3}$ Department of Mechanical and Manufacturing Engineering, University of Manitoba, Winnipeg, Manitoba R3T 5V6, Canada.}

\section{Authors' contributions}

SOO collected the wind data and carried out initial analysis. Wind turbine calculations were performed by MSA. 'Background' section was drafted by SSP. 'Results and discussion' section was jointly drafted by MSA and SSP. All authors read, edited and eventually approved the manuscript to be submitted.

\section{Received: 7 March 2012 Accepted: 25 May 2012}

Published: 25 May 2012

\section{References}

1. Global Wind Energy Council: Global wind report: annual market updates 2011. http://www.gwec.net/ (2011). Accessed 30 April 2012

2. Fagbenle, RO, Katende, J, Ajayi, OO, Okeniyi, JO: Assessment of wind energy potential of two sites in North-East, Nigeria. Renew. Energy 36, 1277-1293 (2011)
3. Ojosu, JO, Salawu, Rl: A survey of wind energy potential in Nigeria. Solar and Wind Technology 7, 155-67 (1990)

4. Adekoya, LO, Adewale, AA: Wind energy potential of Nigeria. Renew. Energy 2, 35-39 (1992)

5. Fadare, DA: The application of artificial neural networks to mapping of wind speed profile for energy application in Nigeria. Applied Energy 87, 934-942 (2010)

6. Adaramola, MS, Oyewola, OM: On wind speed pattern and energy potential in Nigeria. Energy Policy 39, 2501-2506 (2011)

7. Marcius-Kaitis, M, Katnals, V, Karaliauskas, A. Wind power usage and prediction prospects in Lithuania. Renew. Sustain. Energy Rev. 12, 265-277 (2008)

8. Anyanwa, EE, Iwuagwu, CJ: Wind characteristics and energy potentials for Owerri Nigeria. Renew. Energy 6, 125-128 (1995)

9. Asiegbu, AD, Iwuoha, GS: Studies of wind resources in Umudike, south east Nigeria-an assessment of economic viability. J. Eng. Appl. Sci. 2, 1539-1541 (2007)

10. Manwell, JF, McGowan, JG, Rogers, AL: Wind Energy Explained: Theory, Design and Application, 2nd edn. Wiley, Wiltshire (2010)

11. International Standards Organisation: Guide to the Expression of Uncertainty in Measurement, 1st edn. (1992)

12. Akpinar, EK, Akpinar, S: An assessment on seasonal analysis of wind energy characteristics and wind turbine characteristics. Energy Conversion and Management 46, 1848-67 (2005)

13. Justus, CG, Hargraves, WR, Mikhail, A, Graber, D: Methods for estimating wind speed frequency distributions. J. Appl. Meteorol. 17, 350-353 (1978)

14. Akdag, SA, Dinler, A: A new method to estimate Weibull parameters for wind energy applications. Energy Conversion and Management 50, 1761-1766 (2009)

15. Akdag, SA, Bagiorgas, HS, Mihalakakou, G: Use of two-component Weibull mixtures in the analysis of wind speed in the Eastern Mediterranean. Applied Energy 87, 2566-2573 (2010)

16. Mathew, S, Pandey, KP, Kumar, AV: Analysis of wind regimes for energy estimation. Renew. Energy 25, 381-399 (2002)

17. Jowder, FAL: Wind power analysis and site matching of wind turbine generators in Kingdom of Bahrain. Applied Energy 86, 538-545 (2009)

18. Kwon, SD: Uncertainty analysis of wind energy potential assessment. Applied Energy 87, 856-865 (2010)

19. Ouammi, A, Dagdougui, $H$, Sacile, R, Mimet, A: Monthly and seasonal assessment of wind energy characteristics at four monitored locations in Liguria region (Italy). Renew. Sustain. Energy Rev. 14, 1959-1968 (2010)

20. Balouktsis, A, Chassapis, D, Karapantsios, TD: A nomogram method for estimating the energy produced by wind turbine generators. Solar Energy 72, 251-259 (2002)

21. Bagiorgas, HS, Assimakopoulos, MN, Theoharopoulos, D, Matthopoulos, D, Mihalakakou, GK: Electricity generation using wind energy conversion systems in the area of Western Greece. Energy Conversion and Management 48, 1640-1655 (2007)

22. Ucar, A, Balo, F: Evaluation of wind energy potential and electricity generation at six locations in Turkey. Applied Energy 86, 1864-1872 (2009)

23. Ilinca, A, McCarthy, E, Chaumel, J-L, Retiveau, J-L: Wind potential assessment of Quebec Province. Renew. Energy 28, 1881-1897 (2003)

24. Celik, AN: A statistical analysis of wind power density based on the Weibull and Rayleigh models at the southern region of Turkey. Renew. Energy 29, 593-604 (2004)

25. Mathew, S: Wind Energy: Fundamentals, Resource Analysis and Economics. Springer, Heidelberg (2006)

26. Mathew, S, Pandey, KP: Modelling the integrated output of wind-driven roto-dynamic pumps. Renew. Energy 28, 1143-1155 (2003)

27. Hau, E, Renouard, R: Wind turbines: Fundamentals, technologies, applications, economics, 2nd edn. Springer, Heidelberg (2006)

28. Mathew, S, Pandey, KP: Modelling the integrated output of mechanical wind pumps. J. Solar Energy Engineering 122, 203-206 (2000)

29. Fagbenle, RL, Karayiannis, TG: On the wind energy resource of Nigeria. Intern. J. Energy Res. 18, 493-508 (1994)

30. Meel, J, Smulders, P: Wind Pumping: A Handbook (World Bank Technical Paper No. 101). World Bank, Washington (1989)

31. Polaris: http://www polarisamerica.com/ (2011). Accessed 04 April 2011

32. Wind Energy Solutions: http://www.wes30.com/ (2011). Accessed 04 April 2011

33. WinWinD: http://www.winwind.com/Documents/Press\%20Kit/wwd1.pdf (2011). Accessed 04 April 2011 
34. Paul, SS, Oyedepo, SO, Adaramola, MS: Economic assessment of water pumping systems using wind energy conversion systems in the southern part of Nigeria. Energy Exploration and Exploitation 30, 1-18 (2012)

35. Shi, J, Shen ,D, Wei, J: The development of wind pumping technology in China. Biomass 20, 13-23 (1989)

36. Bobs Harries Engineering Ltd: Kijito wind pumps - Pumping water with wind: Information package. Brochure, Bob Harries Engineering Limited (2009)

37. Adelana, SMA, Olashinde, PI, Bale, RB: An overview of the geology and hydrogeology of Nigeria. In: Adelana, S, MacDonald, A (Eds) Applied Groundwater Studies in Africa, pp. 171-197. Taylor and Francis, London (2008)

38. United Nations Development Programme: Human Development Report. United Nations Development Programme, New York (2006)

doi:10.1186/2251-6832-3-7

Cite this article as: Oyedepo et al: Analysis of wind speed data and wind energy potential in three selected locations in south-east Nigeria. International Journal of Energy and Environmental Engineering 2012 3:7.

Submit your manuscript to a SpringerOpen ${ }^{\circ}$ journal and benefit from:

- Convenient online submission

- Rigorous peer review

- Immediate publication on acceptance

- Open access: articles freely available online

- High visibility within the field

- Retaining the copyright to your article

Submit your next manuscript at $>$ springeropen.com 